\title{
Multiple Regions of the NG2 Proteoglycan Inhibit Neurite Growth and Induce Growth Cone Collapse
}

\author{
Yvonne M. Ughrin, ${ }^{\star}$ Zhi Jiang Chen, ${ }^{*}$ and Joel M. Levine \\ Department of Neurobiology and Behavior, State University of New York at Stony Brook, Stony Brook, New York 11794
}

The NG2 chondroitin sulfate proteoglycan, an integral membrane proteoglycan, inhibits axon growth from cerebellar granule neurons and dorsal root ganglia (DRG) neurons in vitro. The extracellular domain of the NG2 core protein contains three subdomains: an $\mathrm{N}$-terminal globular domain (domain 1), a central extended domain that has the sites for glycosaminoglycan (GAG) attachment (domain 2), and a juxtamembrane domain (domain 3). Here, we used domain-specific fusion proteins and antibodies to map the inhibitory activity within the NG2 core protein. Fusion proteins encoding domain 1 (D1-Fc) or domain 3 (D3-Fc) of NG2 inhibited axon growth from cerebellar granule neurons when the proteins were substrate-bound. These proteins also induced growth cone collapse from newborn DRG neurons when added to the culture medium. Domain 2 only inhibited axon growth when the GAG chains were present. Neutralizing antibodies directed against domain 1 or 3 blocked completely the inhibition from substrates coated with D1-Fc or D3-Fc. When the entire extracellular domain of NG2 was used as a substrate, however, both neutralizing antibodies were needed to reverse completely the inhibition. When NG2 was expressed on the surface of HEK293 cells, the neutralizing anti-D1 antibody was sufficient to block the inhibition, whereas the anti-D3 antibody had no effect. These results suggest that domains 1 and 3 of NG2 can inhibit neurite growth independently. These inhibitory domains may be differentially exposed depending on whether NG2 is presented as an integral membrane protein or as a secreted protein associated with the extracellular matrix.

Key words: regeneration; glial scars; chondroitin sulfate proteoglycan; spinal cord injury; NG2; growth cone collapse

\section{Introduction}

The developing and adult brain contains a diverse and complex array of proteoglycans (PGs; Herndon and Lander, 1990). The molecular diversity of PGs arises from both the different polypeptide chains comprising the core proteins and the glycosaminoglycan (GAG) modifications of these core proteins. Proteoglycans vary in their cellular locations and are associated with cell surfaces, the extracellular matrix, and perineuronal nets (for review, see Bandtlow and Zimmermann, 2000; Hartmann and Maurer, 2001). The cellular functions of PGs are as diverse as their structures. One of the most studied functions of PGs in the nervous system is their ability to modulate axonal growth, guidance, and regeneration (Bovolenta and Fernaud-Espinosa, 2000). PGs can directly stimulate or inhibit axon growth, and some PGs act as necessary cofactors that modulate the responses to other guidance factors (Hu, 2001; Ronca et al., 2001). Proteoglycans are found at high levels in glial scars, where they are thought to contribute to the creation of an environment that prevents nerve regeneration (Asher et al., 2001).

One well characterized PG of the nervous system is the NG2 chondroitin sulfate proteoglycan (CSPG; Levine and Nishiyama, 1996). NG2 comprises a large, integral membrane PG with a core protein of $\sim 300 \mathrm{kDa}$ and at least one covalently attached chondroitin sulfate (CS) GAG chain (Nishiyama et al., 1991; Stallcup

Received Aug. 20, 2002; revised 0ct. 8, 2002; accepted 0ct. 11, 2002.

This work was supported by grants from the National Institutes of Health and the Christopher Reeve Paralysis Foundation. We thank Dr. V. Lemmon and J. Raper for gifts of plasmids.

*Y.M.U. and Z.J.C. contributed equally to this work.

Correspondence should be addressed to Dr. Joel M. Levine at the above address. E-mail: joel.levine@sunysb.edu. Copyright $\odot 2002$ Society for Neuroscience $\quad 0270-6474 / 02 / 220175-\bullet \$ 15.00 / 0$ and Dahlin-Huppe, 2001). The large extracellular domain of the core protein can be divided into three smaller domains; an $\mathrm{N}$-terminal globular domain, a central extended domain, and a juxtamembrane domain. Within the CNS, NG2 is found almost exclusively on the surfaces of developing and adult oligodendrocyte precursor cells (Levine et al., 2001). Elsewhere, NG2 is associated with developing chondrocytes, cardiomyocytes, pericytes, and several different human tumors (Levine and Nishiyama, 1996). Because NG2 can be secreted or shed from the cell surface, it also has the potential to become incorporated into the extracellular matrix (ECM) produced by these cell types (Nishiyama et al., 1995). NG2 interacts with a large number of different proteins including ECM molecules and growth factors (Burg et al., 1996; Goretzki et al., 1999). The binding sites for some of these ligands have been mapped to specific regions of the NG2 core protein. For example, type VI collagen binds to the central domain 2, and PDGF-AA and basic FGF (bFGF) bind to separate sites in domains 2 and 3 of NG2 (Tillet et al., 1997; Goretzki et al., 1999). Thus, NG2 is constructed of distinct functional modules.

Purified preparations of NG2 and membrane-associated NG2 inhibit axon growth in vitro (Dou and Levine, 1994; Chen et al., 2002). Because levels of NG2 rapidly increase at sites of CNS injury (Levine, 1994), this inhibitory property may be an important negative factor for CNS regeneration. The regions of the large core protein performing these growth-inhibitory functions have not yet been identified. Here, we have used a combination of domain-specific fusion proteins and monoclonal antibodies to map the growth-inhibitory functions of NG2 to domains 1 and 3 of the core protein. These regions may be differentially exposed depending on whether NG2 is presented as an integral membrane protein or as an extracellular factor. 


\section{Materials and Methods}

Reagents. Unless otherwise noted, all reagents were purchased from Sigma (St. Louis, MO). Plasmid DNA encoding for the extracellular domain of L1 fused to an Fc tail was provided by V. Lemmon (Case Western Reserve University, Cleveland, OH), and plasmid Coll-1-pAG-CT, encoding a chick collapsin-1 myc/his fusion protein (Koppel and Raper, 1998), was a gift from J. Raper (University of Pennsylvania, Philadelphia, PA). Sprague Dawley rats were obtained from Taconic Farms (Germantown, NY) and maintained in the university animal housing facility. All procedures involving animals were reviewed and approved by the local Institutional Animal Care and Use Committee.

Construction of NG2 expression plasmids. cDNA fragments coding for domain 1 (D1, amino acids 30-640), domain 2 (D2, amino acids 6361591), domain 3 (D3, amino acids 1592-2222), and domains 1 and 2 (D1,2, amino acids 30-1591) of NG2 were generated by PCR amplification (Expand high-fidelity PCR system; Roche Molecular Biochemicals, Indianapolis, IN) using a full-length rat NG2 cDNA as a template (pBSNG2, a gift from A. Nishiyama, University of Connecticut, Storrs, CT). The primers used were as follows: for the D1-Fc construct, 5' primer, nucleotides 157-186, 3' primer, nucleotides 1972-1989; for D2Fc, 5' primer, nucleotides 1975-1993, 3' primer 4825-4842; and for D3-Fc, 5' primer, nucleotides $4843-4859,3^{\prime}$ primer, nucleotides $6723-$ 6740. For D1,2-Fc, a 5' primer corresponding to nucleotides $157-186$ and a $3^{\prime}$ primer encompassing nucleotides $4825-4842$ were used. Restriction enzyme digestion sites were incorporated into each primer to facilitate cloning of the amplified fragments into signal pIG plus mammalian expression vector (Novagen, Madison, WI). A control MUC18-Fc expression plasmid was also obtained from Novagen. A cDNA encoding a myc/his fusion protein containing the entire extracellular domain (ECD) of NG2 was constructed in two steps. First, PCR was used to generate a 1012 base pair fragment encoding the region of NG2 from nucleotides 5636-6738. After gel purification, this fragment was ligated into the $\mathrm{XhoI}$ and $\mathrm{XbaI}$ sites of pcDNA3-NG2 (Chen et al., 2002) to generate a cDNA encoding the entire ECD without a transmembrane domain and a cytoplasmic tail. An XbaI-BssHII fragment of this vector was ligated into pcDNA3.1 myc/hisB(-) (Invitrogen, San Diego, CA). A cDNA encoding only D3, the transmembrane region and cytoplasmic domain of NG2, was constructed by digesting the D3-Fc expression plasmid with SpeI. This fragment, which contained part of the cytomegalovirus promoter, the CD33 signal peptide, and the first half of D3, was ligated into a gel-purified fragment of SpeI-digested pcDNA3-NG2 containing the entire NG2 coding region 3' to the SpeI site at nucleotide 6051 and much of the pcDNA3 backbone. The junctions and reading frames of all constructs were verified by restriction mapping and partial DNA sequencing.

Transfection and selection of stable lines. COS-1 and HEK293 cells were maintained in DMEM (Mediatech, Washington, DC) containing 10\% fetal bovine serum (FBS; JRH Biosciences, Lenexa, KS) at $37^{\circ} \mathrm{C}$ and $10 \%$ $\mathrm{CO}_{2}$. For transient transfection, the cells were grown to $\sim 70 \%$ confluence on $100 \mathrm{~mm}$ tissue culture plates and transfected using LipofectAMINE (Invitrogen) according to the manufacturer's recommendations. After 16-24 hr, the transfection media was replaced with $5 \mathrm{ml}$ of Optimem (Invitrogen), and the cells were grown for 3 additional days before collecting the supernatants. Stable expressing cell lines were generated similarly and selected after growth in medium containing G418 (800 $\mu \mathrm{g} / \mathrm{ml}$; Invitrogen).

Protein purification. Fc fusion proteins were purified by passing serum-free conditioned media over protein A-Sepharose columns. After washing with PBS, bound proteins were eluted with $50 \mathrm{~mm}$ glycine, $\mathrm{pH}$ 1.9 , and immediately neutralized with 0.1 volume of $1 \mathrm{M}$ Tris base. After overnight dialysis against PBS, protein concentrations were determined using Micro BCA protein assay reagents (Pierce, Rockford, IL) with bovine serum albumin (BSA) as the standard. The $290 \mathrm{kDa}$ soluble fragment corresponding to the ECD of NG2 was purified from B49conditioned serum-free media by ion exchange chromatography as described previously (Tillet et al., 1997). Two separate fractions of the ECD fragment were eluted from the column at different salt concentrations, one that contained NG2 with attached GAGs ( $0.55 \mathrm{~m}$ fraction) and another comprising the NG2 core protein without covalently attached GAGs $(0.4 \mathrm{~m}$ fraction). The myc/his-tagged fusion protein was purified from conditioned medium using a $1 \mathrm{ml}$ HisTrap column (Amersham Biosciences, Arlington Heights, IL).

Enzymatic treatment of the NG2-Fc chimeras. Purified NG2 fragments were treated with protease-free chondroitinase (C'ase) ABC $(0.01 \mathrm{U} / 2 \mu \mathrm{g}$ of protein; obtained from Roche and Seikagaku Kogyo Co., Tokyo, Japan) at $37^{\circ} \mathrm{C}$ for $1 \mathrm{hr}$ in PBS. D2-Fc was incubated with keratanase $(0.1$ $\mathrm{U} / \mu \mathrm{g}$ of protein; Seikagaku Kogyo) at $37^{\circ} \mathrm{C}$ for $1 \mathrm{hr}$ in $\mathrm{PBS}, \mathrm{pH} 7.4$, containing $2 \mathrm{~mm}$ PMSF. An aliquot from each digestion mixture was assayed by Western blotting with rabbit anti-NG2 antibodies.

Neurite outgrowth assay. Tissue culture substrates were prepared by coating 48-well tissue culture plates (Falcon; Becton Dickinson, Mountain View, CA) with $25 \mu \mathrm{g} / \mathrm{ml}$ poly-L-lysine (PLL) overnight, followed by either $2.5 \mu \mathrm{g} / \mathrm{ml} \mathrm{L1-Fc} \mathrm{alone} \mathrm{or} \mathrm{a} \mathrm{mixture} \mathrm{of} \mathrm{L1-Fc}(2.5 \mu \mathrm{g} / \mathrm{ml})$ and $0.5-60 \mathrm{~nm} \mathrm{Fc}$-fusion proteins for $3.5 \mathrm{hr}$ at $37^{\circ} \mathrm{C}$. The protein-coated surfaces were washed with PBS and incubated in serum-containing medium before seeding with neurons. In the case when substrates were treated with antibodies, the protein-coated surfaces were incubated with monoclonal antibodies at $5 \mu \mathrm{g} / \mathrm{ml}$ for $1 \mathrm{hr}$ at $37^{\circ} \mathrm{C}$ before seeding the neurons. Cerebellar granule neurons were partially purified from trypsin dissociates of postnatal day 3-5 rat cerebella on discontinuous Percoll gradients (Hatten, 1985) and seeded onto protein-coated wells at $2 \times 10^{4}$ cells per well in DMEM containing $10 \%$ FCS, $20 \mathrm{~nm} \mathrm{KCl}$, and $10 \mathrm{ng} / \mathrm{ml}$ bFGF (Peprotech, Rocky Hill, NJ). After $24 \mathrm{hr}$ in culture, the cells were washed in PBS and fixed in PBS containing $2 \%$ glutaraldehyde.

Digital images of the neurons were acquired using an Axiovert microscope (Zeiss, Thornwood, NY) equipped with a charge-coupled device camera (Hamamatsu) and Metamorph Imaging software (Universal Imaging Corp., West Chester, PA). The lengths of at least 50 neurites were measured for each condition. A neurite was defined as a process extending from the cell body by at least $16 \mu \mathrm{m}$ (approximately two cell diameters). In cases in which cells had more than one neurite, only the longest neurite was measured. The mean neurite length for each substrate condition was calculated and averaged across experiments. The percentage of inhibition of neurite growth is defined as $\left[1-\left(\right.\right.$ mean $^{\text {expt }} /$ mean $\left.\left.^{\text {control }}\right)\right] \times 100$, where mean ${ }^{\text {expt }}$ is the mean length under experimental conditions, and mean ${ }^{\text {control }}$ is the mean length of neurites grown on L1 alone for a given data set. Multiple group comparisons were made by a two-tailed ANOVA and Scheffe's post hoc tests (SuperANOVA; Abacus Concepts, Berkeley, CA).

Growth cone collapse assays. Dorsal root ganglia (DRG) were isolated from newborn (postnatal day 0 ) rats and dissociated as described previously (Dou and Levine, 1995). The neurons were plated at a density of 15 cells $/ \mathrm{mm}^{2}$ onto tissue culture wells that had been coated overnight with $50 \mu \mathrm{g} / \mathrm{ml}$ PLL overnight at $37^{\circ} \mathrm{C}$, followed by $10 \mu \mathrm{g} / \mathrm{ml}$ laminin for $2.5 \mathrm{hr}$ at $37^{\circ} \mathrm{C}$. The cells were grown in DMEM containing $10 \% \mathrm{FBS}, 20 \mathrm{~mm}$ $\mathrm{KCl}$, and $60 \mathrm{ng} / \mathrm{ml} \mathrm{NGF}$ (a gift from Dr. L. Mendell, State University of New York at Stony Brook) for $7-8 \mathrm{hr}$ before using in the collapse assays.

For the collapse assays, serial dilutions of test proteins were prepared in tissue culture medium and warmed to $37^{\circ} \mathrm{C}$. Medium was removed from the wells and immediately replaced with the test solutions. After incubation at $37^{\circ} \mathrm{C}$ for $30 \mathrm{~min}$, cultures were quickly washed once in PBS and fixed in $2 \%$ glutaraldehyde in PBS.

To quantitate the effects of the different soluble proteins on DRG growth cones, randomly selected fields of DRG neurons were imaged as described above. Following the suggestion of Cox et al. (1990), a spread growth cone was defined as one having broad lamellipodia and numerous filopodia, whereas a collapsed growth cone had no lamellipodia and few, if any, filopodia. Growth cones that were intermediate in appearance, i.e., small lamellipodia and numerous small filopodia, were not scored because of the inherent ambiguity in classifying them as either spread or collapsed in this type of assay. Each experimental solution was tested in duplicate wells, and $\sim 100$ individual well isolated growth cones were scored from each well. The percentage of collapsed growth cones was calculated from the total number of growth cones scored. Data was normalized to the mean percent collapse of control cultures across all experiments to compare the dose-response curves of the different fusion proteins. Multiple group comparisons were made by a two-tailed ANOVA and Scheffé's post hoc tests (SuperANOVA). 
Membrane carpet assay. The membrane carpet assay was performed as described previously (Tuttle et al., 1995; Chen et al., 2002). For the antibody treatments, the cell membranes were mixed with the purified antibodies at the indicated concentration and incubated on ice for $30 \mathrm{~min}$, and the mixture was used to make the membrane carpets.

Solid-phase ELISAs. ELISAs were performed to measure the amount of Fc fusion protein bound to tissue culture wells used in the neurite outgrowth assays. Either PLL-coated wells were coated with Fc fusion proteins for $3.5 \mathrm{hr}$ at $37^{\circ} \mathrm{C}$ (as in the neurite experiments), or the fusion proteins were added to the wells and then dried under vacuum. Rabbit anti-NG2 (1:2500) and an alkaline phosphatase-conjugated goat antirabbit IgG secondary antibody (1:2500; Southern Biotechnology, Alabaster, $\mathrm{AL}$ ) were used to detect the amount of the NG2-Fc fusion proteins bound. After a $30 \mathrm{~min}$ incubation with the conjugated secondary antibody, wells were washed three times and treated with $p$-nitrophenylphosphate at 1 $\mathrm{mg} / \mathrm{ml}$ in $10 \%$ diethanolamine. After $15 \mathrm{~min}$ at room temperature, the optical density of the wells at $405 \mathrm{~nm}$ was determined. The amount bound after $3.5 \mathrm{hr}$ of incubation was compared with the amount bound after vacuum drying, which was considered indicative of the total amount of input protein. These assays demonstrated that when used at $5 \mu \mathrm{g} / \mathrm{ml}(10-20 \mathrm{nM})$, between 80 and $100 \%$ of the input Fc fusion proteins bound to the PLL-coated surfaces.

Solid-phase binding assays. Maxi-sorp 96-well plates (Nunc, Naperville, IL) were coated overnight with $2-20 \mu \mathrm{g} / \mathrm{ml}$ immunoaffinitypurified L1 (Dou and Levine, 1994) in PBS at $4^{\circ} \mathrm{C}$. The surfaces were then blocked by incubation with $1 \%$ BSA in Tris-buffered saline (TBS; $50 \mathrm{~mm}$ Tris, $\mathrm{pH} 7.5$, and $0.15 \mathrm{M} \mathrm{NaCl}$ ) for $2 \mathrm{hr}$ at $37^{\circ} \mathrm{C}$. Soluble $\mathrm{Fc}$ fusion proteins ( 4 or $40 \mathrm{~nm}$ ) were diluted in TBS containing $0.05 \%$ Tween 20 (TBST) and incubated with substrate-coated wells for $2 \mathrm{hr}$ at $37^{\circ} \mathrm{C}$. After three washes with TBST, the plates were incubated with an HRP-conjugated anti-Fc antibody $(1: 10,000)$ for $1 \mathrm{hr}$ at $37^{\circ} \mathrm{C}$. After three more washes, $50 \mu \mathrm{l}$ of freshly prepared $0.2 \mathrm{mg} / \mathrm{ml} o$-phenylenediamine dihydrochloride in phosphate-citrate buffer was added to each well. After $1 \mathrm{hr}$ at $37^{\circ} \mathrm{C}$, the absorbance at $490 \mathrm{~nm}$ was measured using a plate reader. Wells not coated with L1 were designated blanks, and the readings from these wells were subtracted from the appropriate test wells to exclude nonspecific binding of fusion proteins and antibodies to the surfaces. As a positive control, the binding of NG2-Fc fusion proteins to wells coated with 2 $\mu \mathrm{g} / \mathrm{ml}$ collagen VI (Chemicon, Temecula, CA) was also measured.

Production of monoclonal antibodies. Mice were immunized by intraperitoneal injection of $1 \times 10^{7} 293-\mathrm{NG} 2$ cells or 293-D3 cells three times at 1 week intervals. The mice were allowed to rest for 1 month after the third injection and then were further immunized with a final boost. Fusion of spleen cells with P3xAg8.653 myeloma cells was performed $4 \mathrm{~d}$ after the final boost. Tissue culture supernatants from wells with cell colonies were screened by ELISA, using purified ECD-myc/his or D3-Fc as a target antigen. Positive clones were further screened by immunofluorescence staining of 293-NG2 and 293-D3 cells. The binding specificity of the resulting antibodies was tested by ELISA and immunoblot assays, using ECD-myc/his, D1-Fc, D2-Fc, and D3-Fc as targets. Positive clones were also screened for their ability to neutralize the neurite growthinhibitory activity of NG2 and NG2-derived fusion proteins using the neurite outgrowth assay and the membrane carpet assay described above. Three different monoclonal antibodies (mAbs) designated as 69, 132, and 147 were obtained and selected for further study and analysis. $\mathrm{mAb}$ 69 is an IgG2a, whereas mAbs 132 and 147 are IgG1. Serum-free supernatants were produced from each clone, and the antibodies were purified by affinity chromatography using protein G-Sepharose columns (Amersham Biosciences).

Immunofluorescence staining. The immunofluorescence staining methods were similar to those described previously (Levine and Stallcup, 1987). The following antibodies were used: rabbit anti-NG2 antibody (1:300; Levine and Card, 1987), monoclonal anti-NG2 antibody 69 (antiD1), D31.10 (anti-D2), 147 (anti-D3N), and 132 (anti-D3). All the monoclonal anti-NG2 antibodies were used at the concentration of 1 $\mu \mathrm{g} / \mathrm{ml}$. Cyanine (CY3)-conjugated goat anti-mouse (Jackson ImmunoResearch, West Grove, PA) and FITC-conjugated goat anti-rabbit (Southern Biotechnology; Fisher Scientific, Pittsburgh, PA) antibodies were used as secondary antibodies. Cultures were examined using a Zeiss
Axioplan microscope equipped with fluorescence and differential interference contrast (DIC) optics.

Western blot analysis. Fc and myc/his NG2 fusion proteins were electrophoresed on either 6 or 6-15\% gradient polyacrylamide-SDS gel reducing conditions and immunoblotted as described previously (Levine et al., 1998; Martin et al., 2001) using ECL reagents (Amersham Biosciences). Primary antibodies included a polyclonal anti-NG2 antibody (1:2000) and monoclonal anti-NG2 antibodies 69, D31.10, 147, and 132. All the monoclonal anti-NG2 antibodies were used at $1 \mu \mathrm{g} / \mathrm{ml}$. For detection of the Fc epitope tag, we used an HRP-conjugated anti-human Fc antibody $(1: 25,000)$.

\section{Results}

\section{Generation and characterization of NG2 fusion proteins}

A schematic view of the domain structure of NG2 is shown in Figure $1 A$. To identify those regions of the large NG2 core protein that inhibit neurite outgrowth, we prepared Fc fusion proteins containing each of the three subdomains of the large ECD of NG2 and a fourth Fc fusion protein containing domains 1 and 2 together. The $\mathrm{Fc}$ tail was fused to the $\mathrm{C}$ terminus of each protein. As a control for any effects of the Fc tail, we used a MUC18-Fc fusion protein (Lehmann et al., 1989). We also prepared the entire ECD of NG2 fused at its $\mathrm{C}$ terminus to a myc epitope and six histidine residues (ECD-myc/his). For some experiments, the ECD was purified biochemically from serum-free medium conditioned by B49 cells (Tillet et al., 1997). Each of these soluble proteins was purified from conditioned medium by affinity chromatography as described in Materials and Methods. Figure $1 B$ shows a Coomassie brilliant blue-stained SDS gel of the fusion proteins after purification. Because fusion proteins containing domain 2 are modified with CS GAG chains, they are polydisperse in their molecular weights and difficult to visualize in stained gels. After digestion with chondroitinase $\mathrm{ABC}$, however, each of the $\mathrm{CS}$ GAG-containing fusion proteins electrophoresed as a single polypeptide. (The lower-molecular weight band seen in the lanes marked + is the chondroitinase enzyme.) The ECD-myc/his fusion protein also contained CS GAG chains but was able to enter the $6 \%$ polyacrylamide gels used. Figure $1 C$ shows that each of the domain-specific Fc fusion proteins was detected on immunoblots with polyclonal antibodies raised against native NG2 (left panel) and with anti-human Fc antibodies (rightpanel). As in the stained gel, treatment of domain 2-containing fusion proteins with C'ase reduced the size heterogeneity and increased the amount of the polypeptide band detected. Digestion with keratanase did not alter the molecular weight of domain 2-containing fusion proteins (data not shown). The apparent molecular weights of the fusion proteins were generally $10-20 \%$ higher than the molecular weights predicted from the amino acid sequences; this variation could be attributable to glycosylation, because each domain contains potential sites for the attachment of $\mathrm{N}$-linked carbohydrates (Nishiyama et al., 1991).

\section{Fc fusion proteins inhibit neurite outgrowth in vitro}

We used a neurite outgrowth assay (Dou and Levine, 1994) to measure the ability of different regions of the NG2 core protein to inhibit neurite outgrowth from neonatal rat cerebellar granule neurons. In this assay, neurite growth on surfaces coated with an $\mathrm{L} 1-\mathrm{Fc}$ fusion protein is compared with growth on surfaces coated with both L1- and NG2-containing fusion proteins. L1-Fc robustly promoted the growth of cerebellar granule neurons and was maximally effective when used at $3.0-4.0 \mu \mathrm{g} / \mathrm{ml}$ (mean neurite length, $129 \pm 6.0 \mu \mathrm{m}$; data not shown). Therefore, for the assays described here, we used L1-Fc at $2.5 \mu \mathrm{g} / \mathrm{ml}$, a concentration that promoted $\sim 80-85 \%$ of the maximal neurite outgrowth 
A

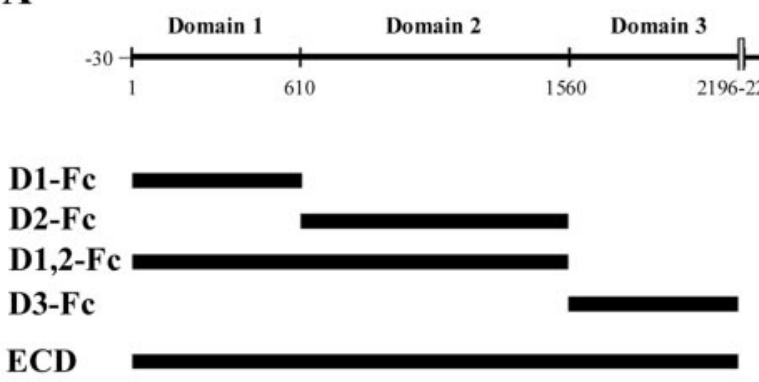

B

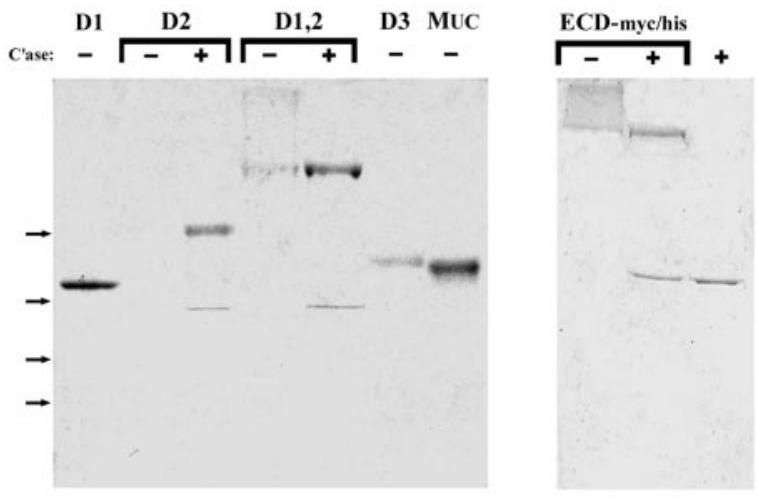

C
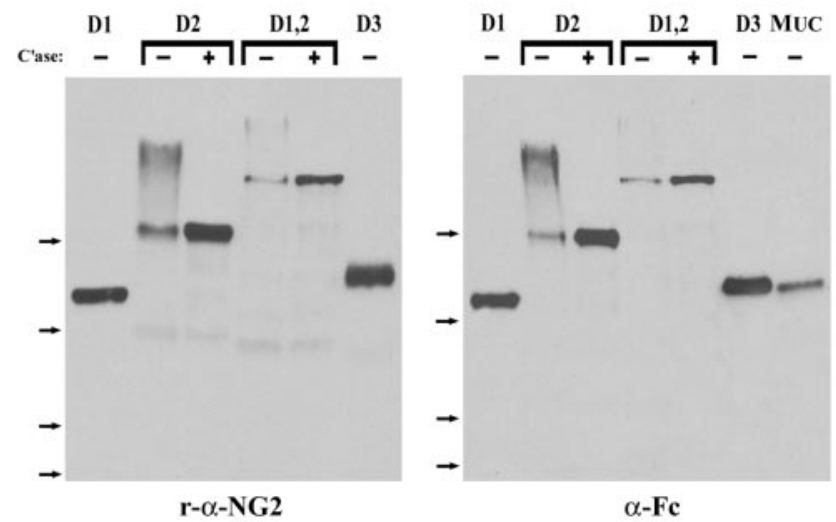

Figure 1. Characterization of the NG2 proteins used in this study. A, Schematic diagrams showing the domain structure of NG2. The numbers in the top panel represent the amino acid residues that constitute the boundaries between domains $1-3$. The positions of the $F$ c fusion proteins and the entire ECD are indicated by the thick bars. $B$, Coomassie brilliant blue-stained gels showing the composition of the NG2-Fc fusion proteins (left panel) and ECD-myc/his fusion proteins (right panel). C, Immunoblots demonstrating that each NG2-F( protein is recognized by polyclonal antibodies against NG2 (left panel) and by a monoclonal antibody against human $\mathrm{Fc}$ (right panel). In both $B$ and $C$, the proteins were electrophoresed on 6-15\% gradient polyacrylamide gels. + , Samples that were treated with chondroitinase $A B C$ before gel electrophoresis; - , untreated samples. The far right lane in $B$ is C'ase $A B C$ alone. The arrows to the left indicate the mobility of molecular weight standards; from top to bottom, they are 182, 121, 86, and $69 \mathrm{kDa}$.

obtainable. To confirm that the NG2-containing fusion proteins bound to the L1-coated surfaces, we used an ELISA as described in Materials and Methods. Greater than $80 \%$ of the input Fcfusion proteins bound to the L1-Fc-coated surfaces (data not shown). We have shown previously that the inclusion of NG2 in
A

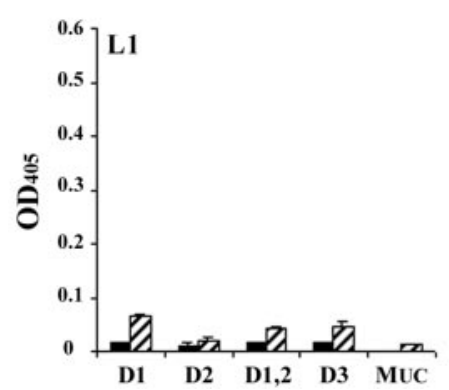

B

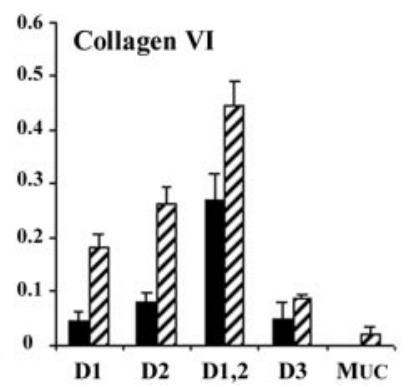

Figure 2. NG2-Fc proteins do not interact directly with L1. Solid-phase binding of NG2-Fc fusion proteins to either L1 or collagen VI was performed as described in Materials and Methods. The indicated Fc fusion proteins were used at either $4 \mathrm{~nm}$ ( filled bars) or $40.5 \mathrm{~nm}$ (hatched bars). Bound ligands were detected with a monoclonal antibody against the Fc tail. Values shown are mean \pm SEM from two separate experiments comprising duplicate wells.

the coating mixtures did not interfere significantly with the binding of L1 or laminin to tissue culture surfaces (Dou and Levine, 1994). Although these data suggest that NG2 and L1 bind independently to the PLL-coated surfaces, they do not rule out a possible direct interaction between NG2 and L1. Other growthinhibitory CSPGs bind to cell adhesion molecules, including L1, neural cell adhesion molecule, and TAG1 (Friedlander et al., 1994; Milev et al., 1996). We determined, therefore, whether the NG2 fusion proteins bind to L1 directly using a solid-phase binding assay as described in Materials and Methods. As shown in Figure $2 A$, there was little direct interaction between the NG2 fusion proteins and L1 when the fusion proteins were tested at either a concentration approximately equal to the $\mathrm{EC}_{50}$ for inhibition of neurite extension (Table 1) or a 10-fold higher concentration. Furthermore, the fusion proteins did not bind to L1coated wells when L1 was used at concentrations as high as 20 $\mu \mathrm{g} / \mathrm{ml}$ (data not shown). Figure $2 B$ shows control experiments in which the binding of the fusion proteins to immobilized type VI collagen was measured. In agreement with previous studies (Tillet et al., 1997), domain 2-containing fusion proteins bound to type VI collagen. Domain 1-Fc also bound to type VI collagen but not as strongly as either D2-Fc or D1,2-Fc. This binding is mediated by the NG2 domains and not the Fc tail, because a control fusion protein, MUC18-Fc, did not bind to either L1 or collagen VI. Together, these data show that (1) NG2-Fc fusion proteins bind to the tissue culture substrates; (2) this binding is independent of the binding of L1 to the surfaces; and (3) the fusion proteins retain at least some of their known biological properties (Tillet et al., 1997).

We tested the ability of the NG2-Fc fusion proteins to inhibit L1-stimulated neurite growth from postnatal cerebellar granule neurons over a range of concentrations. The ECD of NG2 and the $4 \mathrm{Fc}$-fusion proteins derived from the ECD each inhibited neurite growth in a dose-dependent manner (Fig. $3 A$ ). Neurite lengths were significantly shorter $(p<0.001$; ANOVA and Scheffé's post hoc test) compared with the $\mathrm{L} 1$ controls when the $\mathrm{D} 1, \mathrm{D} 1,2$, and D3 fusion proteins were used at $4 \mathrm{~nm}$ or higher. In the case of D2-Fc, neurite lengths were statistically different from those on the L1-coated surface ( $p<0.001$; ANOVA and Scheffe's post hoc test) only when used at $20 \mathrm{~nm}$ or higher concentrations. Over the entire range of concentrations, there were no statistically significant differences between the effectiveness of the four fusion proteins and the ECD ( $p>0.05$; ANOVA and Scheffe's post hoc test). For all the proteins tested, maximal inhibition of between 39 and 
Table 1. Growth-inhibitory activities of NG2 fusion proteins

\begin{tabular}{|c|c|c|c|c|c|}
\hline Condition & Neurite length $(\mu \mathrm{m})$ & Inhibition (\%) & $\mathrm{EC}_{50}(\mathrm{~nm})$ & Collapsed growth cones (\%) & $\mathrm{EC}_{50}(\mathrm{~nm})$ \\
\hline Control & $107.8 \pm 2.8$ & & & $31.2 \pm 0.6$ & \\
\hline ECD & $58.5 \pm 2.1$ & 46.3 & 3.5 & $49.8 \pm 1.5$ & 1.8 \\
\hline D1-Fc & $67.4 \pm 2.6$ & 44.7 & 4.5 & $48.9 \pm 1.2$ & 3.1 \\
\hline $\mathrm{D} 2-\mathrm{Fc}$ & $67.7 \pm 3.8$ & 39.2 & 9 & $48.5 \pm 2.3$ & 3.5 \\
\hline $\mathrm{D} 2-\mathrm{Fc}+$ C'ase & $84.1 \pm 4.5^{*}$ & 24.4 & 22 & $34.4 \pm 1.1^{*}$ & $>20$ \\
\hline $\mathrm{D} 1,2-\mathrm{Fc}$ & $49.6 \pm 2.0$ & 52.6 & 3 & $49 \pm 2.3$ & 2.5 \\
\hline $\mathrm{D} 1,2-\mathrm{Fc}+$ C'ase & $50.6 \pm 2.2$ & 51.7 & 3.5 & $51.1 \pm 0.1$ & 2.4 \\
\hline D3-Fc & $65.6 \pm 2.6$ & 43.4 & 6 & $50.3 \pm 1.4$ & 2.4 \\
\hline
\end{tabular}

Data shown are the mean \pm SEM determined from two to seven experiments for each data set. Percentage of inhibition and percentage of collapse were determined using the fusion proteins at $20 \mathrm{~nm}$. The $\mathrm{EC}_{50}$ values were calculated from the data shown in Figures 3 and 4. C'ase indicates that the proteins were treated with chondroitinase ABC as described in Materials and Methods.

*Values were not significantly different from control values ( $p>0.05$; ANOVA and Scheffé's post hoc test).

$51 \%$ was achieved at a 20 nM concentration (Table 1). This inhibition of neurite extension was not attributable to the Fc tail on these proteins, because surfaces coated with MUC18-Fc, a member of the Ig superfamily, were not inhibitory for neurite growth. Thus, the inhibitory activity of the different NG2 fusion proteins is a specific function of the NG2 portion of these molecules.

Because fusion proteins containing domain 2 have attached CS GAG chains, we evaluated the contribution of the GAGs to growth inhibition by treating the D1,2 and D2 fusion proteins with C'ase to remove the GAG chains. Removing the GAG chains from D1,2-Fc had no effect on the ability of the protein to inhibit neurite outgrowth (Fig. 3B). After removing the GAG chains from D2-Fc, however, the protein was less effective as an inhibitor of neurite extension, and approximately fourfold to fivefold higher concentrations of chondroitinase-treated D2-Fc were needed to achieve the same extent of inhibition as without enzyme treatment. Figure $3 C-K$ shows examples of the neurons grown under some of the conditions tested. With the exception of shorter neurites, no morphological differences were noted across the various growth conditions used. These data demonstrate that two different regions of the NG2 core protein, domains 1 and 3, can inhibit axon growth. The polypeptide core of domain 2 is inhibitory only when used at high concentrations. Although the CS GAG chains associated with domain 2 contribute to growth inhibition, they do not do so when domain 1 is present.

\section{NG2 fusion proteins induce growth cone collapse}

The assays used above measure growth inhibition after $24 \mathrm{hr}$ exposure to the fusion proteins. The rapid effects of growth-inhibitory molecules are often manifested as growth cone collapse. To determine whether acute exposure to soluble fragments of NG2 can induce growth cone collapse, we measured the effects of adding the fusion proteins to cultures of newborn rat DRG neurons as described in Materials and Methods. As shown in Figure 4A, our panel of NG2-derived fusion proteins all induced the collapse of growth cones of postnatal day 0 rat DRG neurons when added in a soluble form. Under control conditions, $\sim 30 \%$ of all the growth cones analyzed were in a collapsed state. This increased to $\sim 50 \%$ when the fusion proteins were added at their maximally effective concentrations (Table 1). There were no significant statistical differences among the effects of the different NG2 fusion proteins; all of them were as effective as the entire ECD, and all were significantly different from the control basal state (Table 1). Figure 4, $C$ and $D$, shows the appearance of an untreated control DRG neuron and a neuron treated with D3-Fc. Simply replacing the medium bathing the cells with fresh control medium or with medium containing the MUC-Fc fusion protein did not induce growth cone collapse. When the cultures were treated with saturating concentrations of a collapsin 1-myc/his fusion protein (Koppel and Raper, 1998), 49\% of the growth cone collapsed (data not shown). Thus, the NG2 fusion proteins were as effective as collapsins in inducing the collapse of growth cones of newborn rat DRG neurons.

We analyzed the role of the CS GAG chains in growth cone collapse by treating the D2-containing fusion proteins with GAG lyases before adding them to the cells. As illustrated in Figure $4 B$, removal of the GAG chains did not alter the collapse response induced by D1,2-Fc. Consistent with the effects of C'ase in the neurite outgrowth assay, removal of the GAG chains from D2-Fc reduced the collapse response to a level not significantly different from that of the control. Treatment of the D2-Fc fusion proteins with keratanase had no effect on the ability of the fusion protein to induce growth cone collapse. Thus, as is the case with inhibition of neurite growth, the CS GAG chains on domain 2 can induce growth cone collapse, but they are not required when core protein regions from domain 1 are present. Consistent with the idea that the GAG chains and protein domains can each independently induce growth cone collapse, we found that the addition of chondroitin 4 -sulfate alone at $5 \mu \mathrm{g} / \mathrm{ml}$ increased the total number of collapsed growth cones to $42 \%$ (data not shown; $p$ vs control $<0.03$; Student's $t$ test).

Table 1 summarizes the data from both the neurite outgrowth and growth cone collapse assays. When used at $20 \mathrm{~nm}$, there were no statistically significant differences between the effects of the entire ECD and the domain-specific fusion proteins in these assays. The $\mathrm{EC}_{50}$ values for each fusion protein for either neurite extension or growth cone collapse, calculated from the data shown in Figures 3 and 4, are similar and in agreement with the $K_{\mathrm{d}}$ for NG2 binding to neurons (Dou and Levine, 1997). The $\mathrm{EC}_{50}$ for D2-Fc in both assays increased twofold to fivefold after removal of the GAG chains. This suggests that the central region of the protein core of NG2 alone has little effect on growing neurons and that most of the inhibitory activity can be attributed to the GAG chains. Whether the CS GAG chains directly perturb axon behavior or whether they are required to hold domain 2 in a conformation that allows it to interact with neurons and their growth cones is unknown.

\section{NG2 can exist in multiple configurations}

In the assays above, the $\mathrm{N}$-terminal domain 1 and the juxtamembrane domain 3 were equally effective when tested separately, and their individual effects were not statistically different from the effects of the entire ECD. NG2 can exist in several different forms. In addition to being an integral membrane proteoglycan, it can be secreted or shed from the surfaces of some tissue culture cell lines (Nishiyama et al., 1995). NG2 is found in both soluble and particulate extracts of normal and injured brain, suggesting that these two forms (a membrane-bound form and a released, extracellular form) occur in vivo (Asher et al., 2001; Jones et al., 2002). These two different structural states suggest the following model. When NG2 is an integral membrane protein, domain 1 may ex- 
tend away from the cell surface and be available for interactions with neuronal growth cones. The juxtamembrane domain 3 may be inaccessible. When secreted or shed from the cell surface, NG2 could associate with the extracellular matrix, perhaps via its central domain 2 , and then both domains 1 and 3 would be accessible. One way to test these speculations would be to derive domain-specific antibodies that can neutralize the inhibitory effects of the individual Fc fusion proteins and then to determine whether the antibodies can neutralize the effects of NG2 when presented as either an integral membrane protein or as an extracellular protein.

\section{Derivation of domain-specific, neutralizing monoclonal antibodies}

To raise domain-specific mAbs, mice were immunized with 293-NG2 cells, which express full-length NG2 as an integral membrane protein (Chen et al., 2002), and with HEK293 cells, which express a truncated NG2 containing extracellular domain 3, the transmembrane domain, and the cytoplasmic tail. The domain specificity of the resulting antibodies was assayed with ELISAs, immunoblots, and indirect immunofluorescence of living cells. Here, we describe four antibodies used. Antibody 69, an IgG2a, is directed against domain 1 and referred to as anti-D1. Antibody D31.10 (Stallcup et al., 1983), an IgG1, is directed against domain 2 and referred to as anti-D2. Two different antibodies against domain 3 were used. The first, antibody 132, an IgG1, bound to D3-Fc but did not neutralize its growth-inhibitory activity. This antibody will be referred to as anti-D3. A second antidomain 3 antibody, antibody 147, also an IgG1, did neutralize domain 3 (see below) and is referred to as anti-D3N. The specificity of the different antibodies in immunoblots is shown in Figure 5.

\section{Monoclonal antibodies block the inhibitory activities of D1,2 and D3}

We tested the ability of the different $m A$ bs to neutralize NG2-induced growth inhibition using the neurite outgrowth assay and the Fc fusion proteins described above. (We used $\mathrm{D} 1,2-\mathrm{Fc}$ in these assays, because the D1-Fc was produced at a low yield and tended to aggregate after storage at $-70^{\circ} \mathrm{C}$.) Each protein was used at $20 \mathrm{~nm}$, and each antibody was used at $5 \mu \mathrm{g} / \mathrm{ml}$. Figure $6 \mathrm{~A}$ shows that anti-D1 completely blocked the inhibitory activity of $\mathrm{D} 1,2-\mathrm{Fc}$ but had no effect on the inhibition of growth on D3-Fccoated surfaces. The anti-D1 mAb also completely reversed the growth inhibition caused by D1-Fc (data not shown). The anti-D2 $\mathrm{mAb}$, which binds to D1,2 to an extent similar to that of

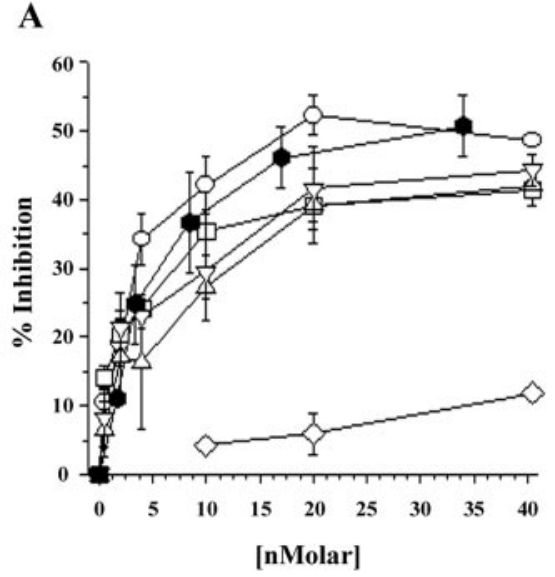

B
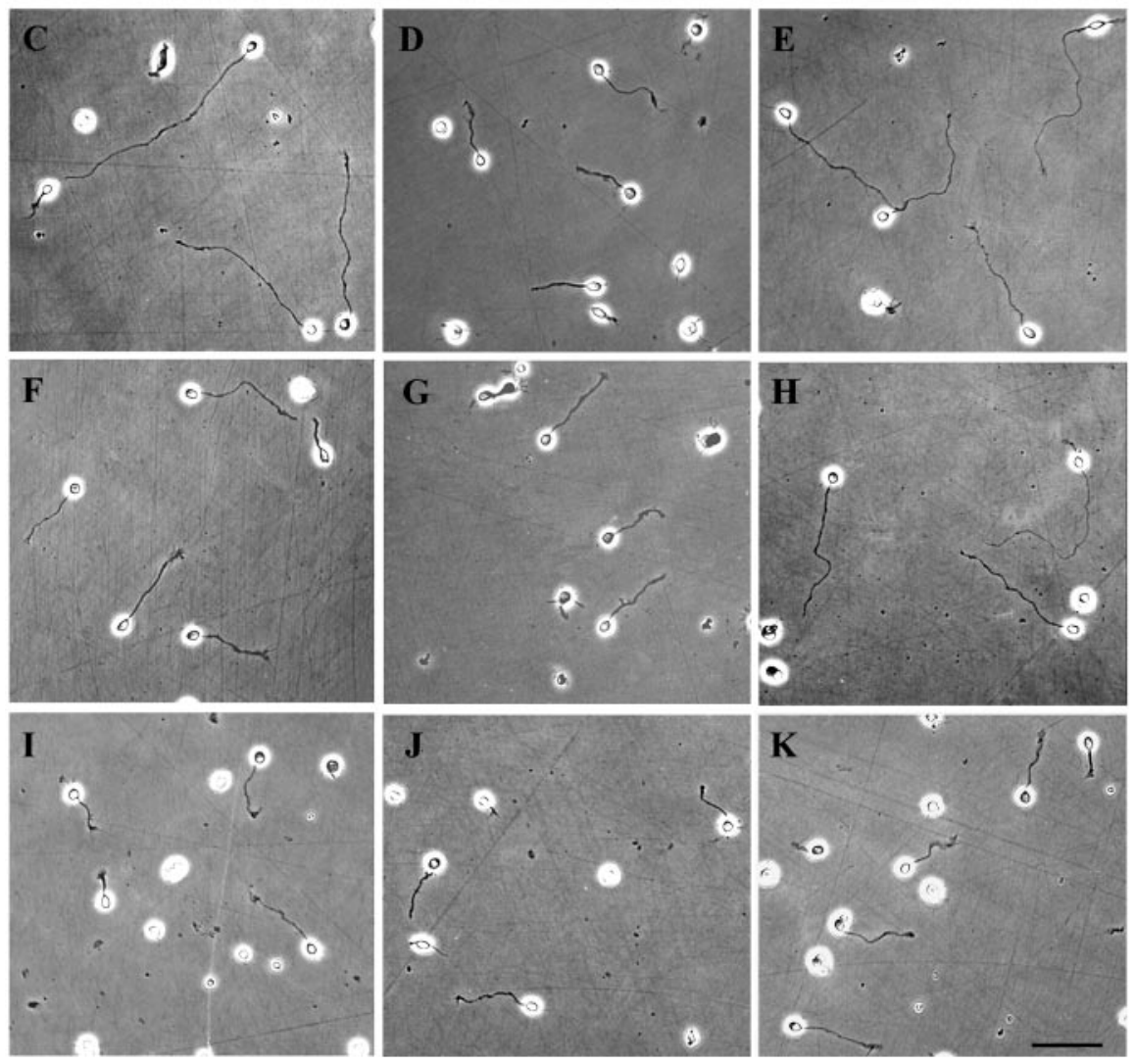

Figure 3. Multiple domains of NG2 inhibit L1-stimulated neurite outgrowth from cerebellar neurons. Neurite length on different surfaces was measured as described in Materials and Methods. $A$, The percentage of inhibition of neurite length ( $y$-axis) for each substrate condition is plotted against the concentration of test protein ( $x$-axis): D1- Fc $(\square), \mathrm{D2}-\mathrm{Fc}(\triangle), \mathrm{D} 1,2-\mathrm{Fc}(\bigcirc), \mathrm{D} 3-\mathrm{Fc}(\nabla), \mathrm{ECD}(\bullet)$, and MUC-Fc $(\diamond) . B$, Effects of C'ase digestion. Domain 2-containing fusion proteins were treated with C'ase as described in Materials and Methods, and the effects of this digestion on the inhibition of neurite outgrowth was measured and analyzed as in $A$. The response to $\mathrm{D} 2-\mathrm{Fc}(\triangle)$ is reduced after treatment with C'ase $(\mathbf{\Delta})$, whereas the response to D1,2- $\mathrm{Fc}(O)$ is not changed after digestion $(\mathbf{O})$. C $-K$, Appearance of cerebellar neurons on the different substrates. All the proteins were used at $20 \mathrm{~nm}$ unless indicated otherwise. The substrates are as follows: $C, \mathrm{~L} 1-\mathrm{FC}$ alone or L1-Fc mixed with D, ECD (17 nm); E, MUC-Fc; F, D1-Fc; G, D2-Fc; H, C'ase-digested D2-Fc; I, D1,2-Fc;J, C'ase-digested D1,2-Fc; and K, D3-Fc. L1-Fc was used at $2.5 \mu \mathrm{g} / \mathrm{ml}$ throughout. Scale bar, $50 \mu \mathrm{m}$.

anti-D1 (data not shown), had no effect on the inhibition caused by D1,2-Fc. This suggests that the core protein regions recognized by the anti-D2 $\mathrm{mAb}$ make little contribution to the inhibitory effects of NG2 (Fig. 6B). Treatment of the D3-Fc-coated surfaces with anti-D3N completely reversed the growth inhibition, but treatment of the surfaces with the same concentration of a second mAb (anti-D3) had no effects. Anti-D3N had no effect on the inhibition caused by D1,2-Fc (Fig. 6C,D). These data demonstrate 
A
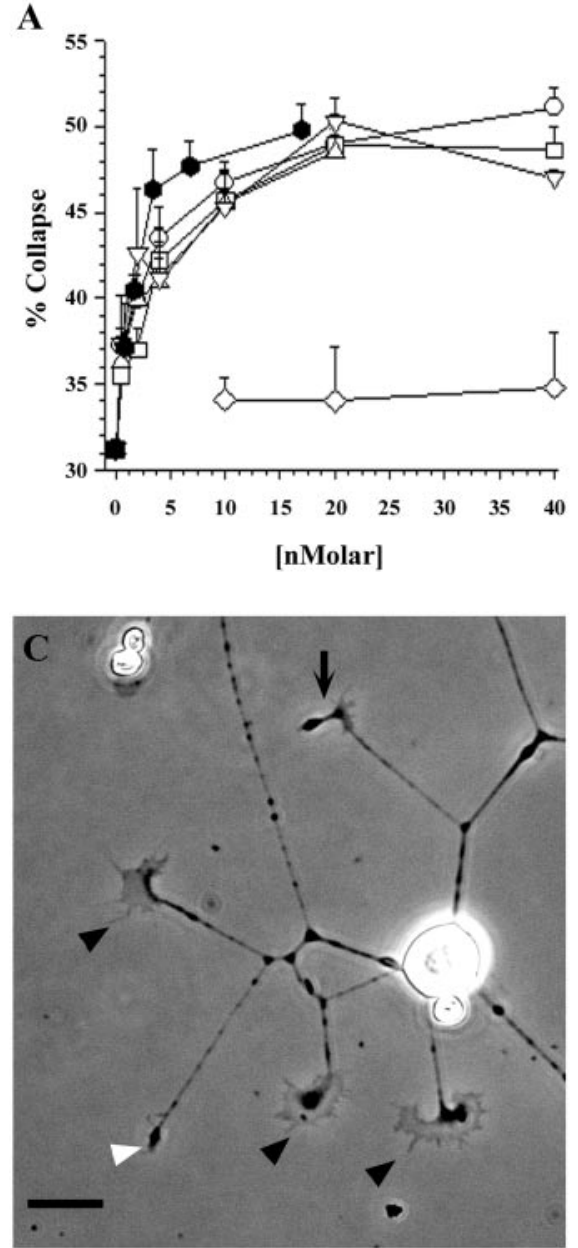

B
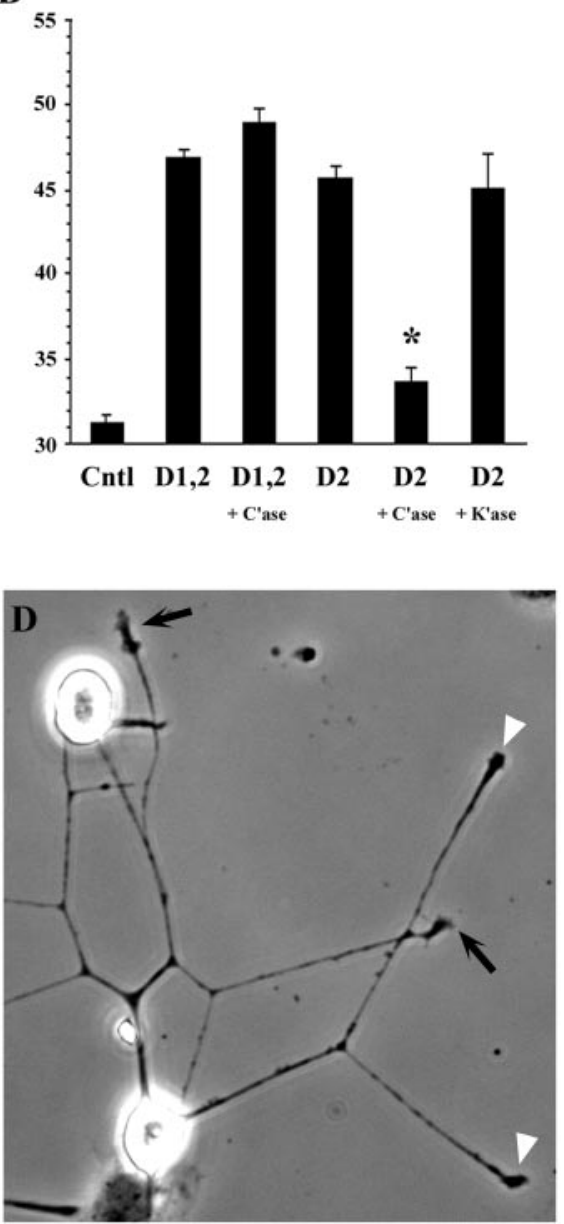

Figure 4. Domain-specific NG2 proteins induce the collapse of DRG neuron growth cones. DRG sensory neurons were grown on laminin for 7-8 hr and then treated with varying concentrations of NG2 fusion proteins for $30 \mathrm{~min}$, fixed, and analyzed as described in Materials and Methods. A, Dose-response curves showing the collapsing activity of the different NG2 proteins. The percentage of growth cones having a collapsed morphology for each condition ( $y$-axis) is plotted against the concentration of the test protein (x-axis): D1-Fc $(\square), \mathrm{D} 2-\mathrm{Fc}(\triangle), \mathrm{D} 1,2-\mathrm{Fc}(O), \mathrm{D} 3-\mathrm{Fc}(\nabla), \mathrm{ECD}-\mathrm{myc} /$ his $(\bullet)$, and MUC-Fc $(\diamond)$. B, Effects of treatment of D2containing fusion proteins with GAG lyases. D2-Fc and D1,2-Fc (10 nM) were treated with the indicated GAG lyases as described in Materials and Methods and then analyzed for growth cone-collapsing activity. C'ase, Digestion with chondroitinase ABC digestion; $K^{\prime} a s e$, digestion with keratanase. All conditions were significantly different from no-protein controls ( $p<0.0001$, ANOVA and Scheffé's post hoc test), except C'ase-treated D2-Fc, which was not significantly different from controls. Values shown in $A$ and $B$ are mean \pm SEM of two to four separate experiments. In all experiments, at least 100 growth cones were scored in each of duplicate wells per condition tested. $C, D$, Representative DRG neurons grown under control conditions $(C)$ and fusion protein-treated conditions ( $D ; D 3-F c, 20 \mathrm{~nm}$ ). The filled arrowheads point to spread growth cones; the open arrowheads point to collapsed growth cones; and the arrows point to unscored growth cones. Scale bar, $20 \mu \mathrm{m}$.

that the mAbs produced can neutralize the growth-inhibitory properties of their respective antigens with little effect on the activities of other regions of the large core protein.

\section{Both domains 1 and 3 contribute to the inhibition of secreted NG2}

To determine which regions of NG2 mediate growth inhibition when the protein is secreted or shed from cells and tissues, we tested the ability of the domain-specific antibodies to neutralize the inhibitory effects of the ECD-myc/his fusion protein on neurite outgrowth. This protein extends from the $\mathrm{N}$ terminus to the juxtamembrane alanine residue (residue 2223) and encompasses regions contained in all secreted forms of NG2 (Nishiyama et al., 1995). As shown in Figure 6E, anti-D3N and anti-D1, when used alone, only partially reversed the inhibitory effects of the ECD.
Anti-D2 antibodies had no effect on this inhibition. We next asked whether pairs of the monoclonal antibodies could reverse more completely the inhibition caused by the ECD. When any two antibodies were used, there was a small reduction in the ability of L1 to promote neurite extension, probably reflecting some shielding of L1 (Fig. 6E, right panel). However, when the L1- and ECD-coated surfaces were treated with both anti-D3N and anti-D1, neurite lengths were increased and became statistically identical to the lengths on the control L1-coated surfaces. Treatment with pairs of nonneutralizing antibodies, such as anti-D2 and anti-D3, did not reduce the inhibition caused by the ECD. Combining the anti-D2 antibodies with either anti-D1 or anti-D3N did not enhance the ability of these neutralizing antibodies to reverse the ECD-mediated growth inhibition (data not shown). These results support the hypothesis that both domains 1 and 3 contribute to the growth-inhibitory activity of NG2 when it is secreted and extracellular.

\section{Domain 1 accounts for most of the inhibitory activity of membrane-associated NG2}

To determine the contributions of domains 1 and 3 to the inhibitory activity of NG2 when it is expressed as an integral membrane protein, we used our domain-specific antibodies in a membrane carpet assay. Although this assay accurately reflects the growth-modulating properties of the tissues or cells from which the membranes are prepared (Tuttle et al., 1995; Chen et al., 2002), it tends to underestimate the potency of growth-inhibiting membranes. Explants with little or no neurite outgrowth attach poorly and tend to be washed away during the vital staining procedures. As shown previously (Chen et al., 2002), membranes prepared from NG2-expressing 293 cells (293NG2) inhibited neurite outgrowth from postnatal cerebellar explants in this assay, and treatment of the membranes with polyclonal anti-NG2 neutralizes this inhibition (Fig. 7). When the 293-NG2 cell membranes were treated with anti-D1 before making the carpets, neurite outgrowth was identical to that on membranes from untransfected 293 cells, demonstrating complete reversal of growth inhibition. Treatment of the 293-NG2 cell membranes with anti-D3N had no effect on the neurite growth inhibition. As expected from the results above, anti-D2 did not reverse the inhibition. Anti-D1 treatment did not reverse the inhibition from myelin-associated glycoprotein (MAG)-expressing Chinese hamster ovary cell membranes (data not shown), demonstrating that the neutralizing effect of anti-D1 is specific for NG2. These experiments suggest that when NG2 is expressed on the cell surface, domain 1 accounts for most of its inhibitory activity. 
Inhibitory regions of domain 3 are inaccessible when membrane-bound The data presented above support the model of NG2 action described above. This model hypothesizes that regions of domain 3 that are critically important for neurite growth inhibition may be inaccessible when NG2 is expressed as an integral membrane proteoglycan, but this region becomes accessible when NG2 is secreted or shed from the cell surface. Regions of domain 1, on the other hand, may be accessible when NG2 is in either the membrane-associated or secreted conformation. Because the anti-D1 and anti-D3 mAbs described here were selected after screening with an ELISA using ECD-myc/ his as a target, they all bind to the extracellular or secreted forms of NG2. We examined whether the antibodies bound to integral membrane NG2 by indirect immunofluorescence staining of living 293-NG2 and 293-D3 cells. As shown in Figure 8, anti-D1, anti-D2, and anti-D3 all bound to the surfaces of the 293-NG2 cells. Anti-D3N, however, bound much more poorly to the cell surface. Both the anti-D3 and anti-D3N antibodies bound to the surfaces of living 293-D3 cells (Fig. $8 M-R$ ). This demonstrates that the failure of anti-D3N to stain the 293-NG2 cells is not attributable to the antibody but to the accessibility of the antigen. The region of domain 3 recognized by this neutralizing antibody is only accessible when NG2 is either extracellular or severely truncated in the membrane.

\section{Discussion}

The glial scar that forms after brain or spinal cord injury is a barrier to axon regeneration, and the CSPGs present at the glial scar, together with myelin-associated inhibitory molecules such as NOGO, are responsible, at least in part, for these barrier functions (Davies et al., 1999; GrandPre et al., 2002). Numerous studies show that levels of NG2 increase rapidly after injury (Levine, 1994; Ong and Levine, 1999; Zhang et al., 2001; Jones et al., 2002; Moon et al., 2002) and that NG2 can inhibit axon growth in vitro (Dou and Levine, 1994; Fidler et al., 1999; Chen et al., 2002). Thus, NG2 may be one of the principal CSPGs involved in preventing axon regeneration. One goal of this study was to identify the specific regions of the NG2 core protein responsible for this inhibition of axon growth.

The data presented here identify the $\mathrm{N}$-terminal domain 1 and the juxtamembrane domain 3 as two regions of NG2 that can inhibit axon growth. When presented in a soluble form, NG2 and fragments thereof induce growth cone collapse. This novel function for NG2 suggests that it is similar to other axon guidance molecules that collapse and repel growth cones. The $\mathrm{EC}_{50}$ values for both the inhibition of neurite extension and growth cone collapse are similar to each other and similar to the $K_{\mathrm{d}}$ for NG2 binding to cerebellar neurons (Dou and Levine, 1997), suggesting that these phenomena are all linked. They suggest a model in which NG2 binds to the neuronal surface and perturbs growth cone functions and structure, and this perturbation subsequently leads to shorter axons.

The primary structure of NG2 bears little resemblance to other proteins or proteoglycans. This is unusual, because most proteoglycans belong to extended families of molecules. Despite the uniqueness of its primary structure, NG2 is highly conserved, and NG2-like molecules have been identified in sea urchins and

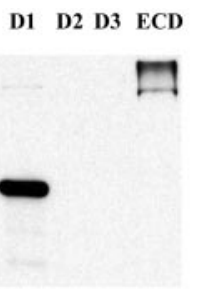

anti-D1

(Mab 69)

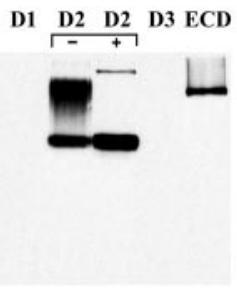

anti-D2

(D31.10)

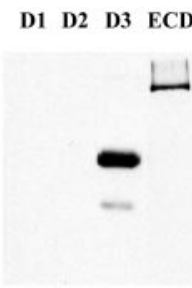

anti-D3N

(Mab 147)
D1 D2 D3 ECD

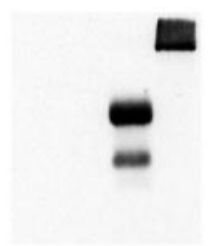

anti-D3

(Mab 132)

Figure 5. Characterization of the domain-specific monoclonal antibodies. Fc-fusion proteins encoding the indicated domains of NG2 were elecfophoresed on 6\% polyacrylamide gels as described in Materials and Methods and immunoblotted with the different anti-NG2 antibodies. The Both mAbs 147 and 132 recognize D3 butnotD1 or D2. All of the antibodies used recognize the ECD. Each lane was loaded with $200 \mathrm{ng}$ of protein. The retic mobility of molecular weight markers. From top to bottom, they are 185, 121, 86, and $69 \mathrm{kDa}$.

Caenorhabditis elegans (Hodor et al., 2000; Hutter et al., 2000). In sea urchin embryos, ECM3, an NG2-like molecule, is thought to form a barrier between ectoderm and endoderm, a function not unsimilar to the proposed role of CSPGs in the developing nervous system and at glial scars (Snow et al., 1990; Oakley and Tosney, 1991; Fawcett and Asher, 1999; Asher et al., 2001).

Domain 1 alone can induce growth cone collapse and can inhibit neurite extension. This is the first demonstrated function for domain 1, which has been difficult to purify and analyze, in part because of its insolubility and tendency to aggregate (Y. M. Ughrin and J. M. Levine, unpublished observations). Domain 1 contains two tandem laminin $\mathrm{G}$ domains, a globular motif found in several proteins, including the neurexins, agrin, caspr, and slit (for review, see Timpl et al., 2000). Laminin G domains bind to heparin, sulfatides, and $\alpha$-dystroglycan (Talts et al., 1999) and participate in cell-cell and cell-matrix interactions. These interactions and their cellular effects are complex, in part because of the structural diversity of the laminin G domains and their ability to interact cooperatively. For example, the three laminin $\mathrm{G}$ domains that are clustered at the $C$ terminus of agrin are not involved in the inhibition of neurite outgrowth from ciliary ganglia neurons (Bixby et al., 2002). Similarly, in the case of slit, a soluble axon repellent, axon repulsion is mediated by the $\mathrm{N}$-terminal leucine-rich repeats and not the single laminin $\mathrm{G}$ domain (Battye et al., 2001; Chen et al., 2001). On the other hand, the laminin G domains of Gas6 are sufficient to bind to and activate the Rse receptor-tyrosine kinase, and the laminin G domains of agrin are responsible for acetylcholine receptor clustering (Mark et al., 1996; Cornish et al., 1999). Whether the laminin G domains of domain 1 are essential for the inhibitory activities demonstrated here is not known.

The central domain 2 of NG2 is thought to have an extended but flexible structure, to carry the single covalently attached CS GAG chain, and to interact with ECM molecules such as collagen V and VI (Tillet et al., 1997; Stallcup and Dahlin-Huppe, 2001). When domain 2 is expressed as a small fusion protein and when it carries one or more CS GAG chains, it inhibits neurite growth and induces growth cone collapse. This activity is likely attributable to the GAG chains and not the core protein, because when the GAG chains are removed with C'ase, domain 2 is essentially inactive. The lack of an inhibitory function for domain 2 is also supported by the observation that all the activity of D1,2-Fc can be neutralized with an antibody that reacts specifically with domain 1 , and that antibodies against both domain 1 and 3, when used together, completely neutralize the inhibitory activity of the 


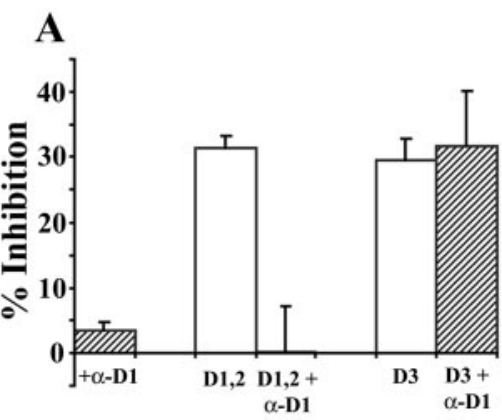

B

C

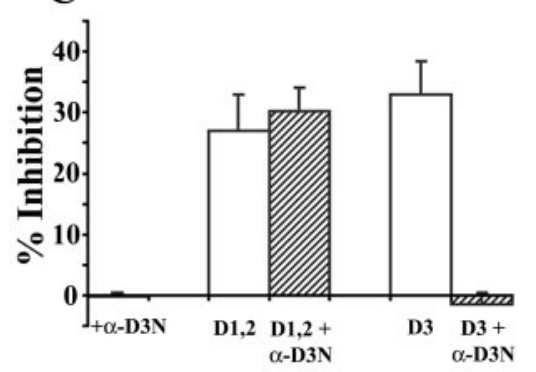

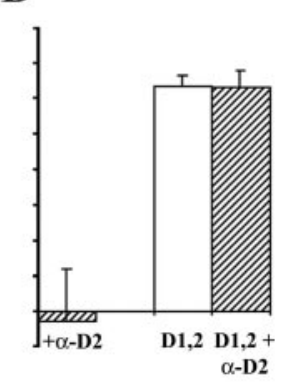

D

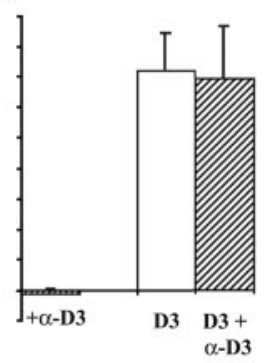

$\mathbf{E}$

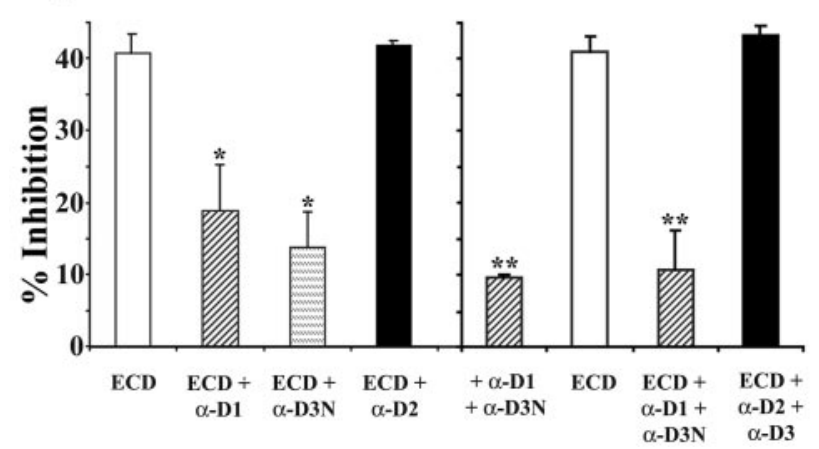

Figure 6. Monoclonal antibodies block neurite growth inhibition caused by the NG2 fusion proteins. Forty-eight-well tissue culture plates were coated with mixtures of L1-Fc and the NG2 fusion proteins and treated with monoclonal antibodies, and neurite lengths were measured for cerebellar granule neurons as described in Materials and Methods. L1-Fc was used at $2.5 \mu \mathrm{g} / \mathrm{ml}$; $\mathrm{D} 1,2-\mathrm{Fc}(D 1,2), \mathrm{D} 3-\mathrm{Fc}(D 3)$, and ECD-myc/his (ECD) were used at $20 \mathrm{~nm}$. All the monoclonal antibodies were used at $5 \mu \mathrm{g} / \mathrm{ml}$. In all panels, neurite growth on substrates coated with L1- $\mathrm{Fc}$ alone was measured and used as $0 \%$ inhibition and is not shown on the graphs. As shown in $A$ and C, the anti-D1 and anti-D3N antibodies completely block neurite growth inhibition induced by their respective antigens but have no effect on the neurite growth inhibition induced by nonreactive fusion proteins. $B, D$, The anti-D2 and anti-D3 antibodies do not reverse the growth inhibition induced by their corresponding antigenic fusion proteins. When ECD-myc/his was used as the substrate, anti-D1 or anti-D3N treatment each only partially reversed growth inhibition ( $E$, left). However, when both the anti-D1 and anti-D3N antibodies were used together to treat the ECD substrate, neurite lengths were comparable with those on L1-coated substrates also treated with both antibodies ( $E$, right). Treatment of the ECD-coated substrates with anti-D2 or anti-D2 together with anti-D3 has no effect on the inhibitory activity of the ECD. Data shown are mean \pm SEM from at least three independent experiments. In each experiment, neurite lengths were measured from at least 50 neurons for each condition. *Value significantly different from ECD ( $p<0.001$; Student's $t$ test) but not significantly different from each other $(p>0.1$; Student's $t$ test); **value significantly different from ECD $(p<0.001$; Student's $t$ test) but not significantly different from each other ( $p>0.4$; Student's $t$ test).

ECD. In previous studies, we have shown that neither chondroitin sulfate A nor chondroitin sulfate C inhibits L1-stimulated neurite growth from cerebellar granule neurons unless used at concentrations many time higher than used here (Dou and Levine, 1995). Thus, the role of the GAG chains in axon growth inhibition is uncertain. It is possible that the clustered negative
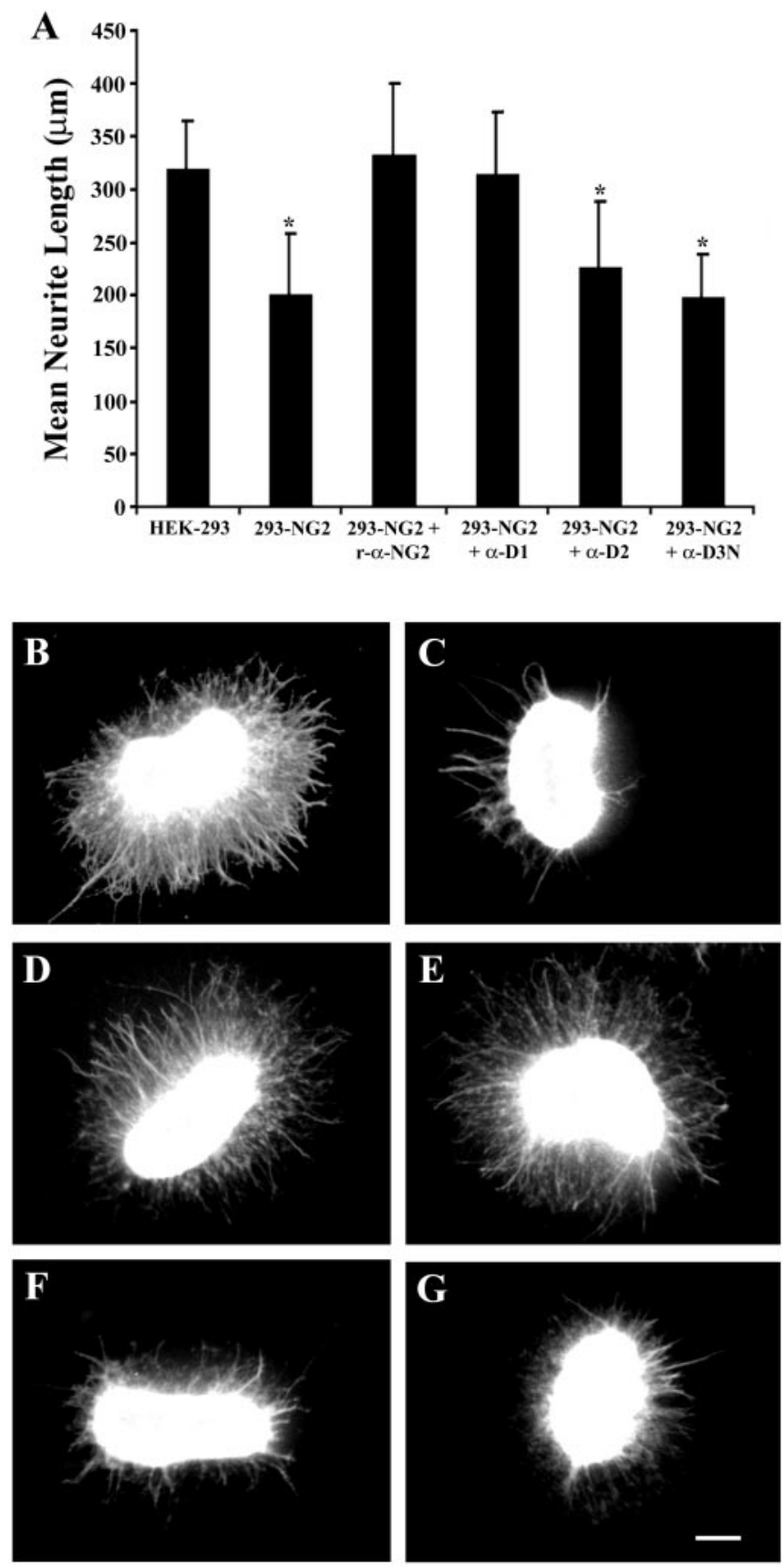

Figure 7. Domain 1 accounts for most of the inhibition caused by integral membrane NG2.A, Cerebellar explants from postnatal day 5-7 rats were grown for $40-44 \mathrm{hr}$ on membrane carpets prepared from untransfected 293 cells, 293-NG2 cells, and 293-NG2 cell membranes treated with either polyclonal anti-NG2 antibodies or the anti-D1, anti-D2, and anti-D3N monoclonal antibodies. Data shown are mean \pm SEM from at least three independent experiments. Between 16 and 34 individual explants were measured for each data point. ${ }^{*} p<0.001$ versus HEK-293; Student's $t$ test. $B-G$, Appearance of the explants on the different membrane substrates: B, 293 cells, C, 293-NG2 cells; D, 293-NG2 cells treated with rabbit anti-NG2; E, 293-NG2 cells treated with anti-D1; F, 293-NG2 cells treated with anti-D2; and G, 293-NG2 cells treated with anti-D3N. Scale bar, $200 \mu \mathrm{m}$.

charges provided by both the CS GAG chain and regions of domain 2 (Nishiyama et al., 1991) combine to perturb growth cone function, but that when either the domain 2 core protein or GAG chains are used individually, the clustered negative charges on these molecules are insufficient to do so. Alternatively, the GAG chains may hold the flexible domain 2 in a configuration that allows for inhibition of growth. 
This finding points out one of the important questions in PG biology: What are the functions of the GAG chains? Several growth-inhibitory PGs, including NG2, neurocan, and versican, do not require the GAG chains for their neurite growthinhibitory activities (Dou and Levine 1994; Friedlander et al., 1994; Milev et al., 1994; Schmalfeldt et al., 2000). In the case of brevican, however, the CS GAG chains contribute significantly to growth inhibition (Yamada et al., 1997). The administration of GAG lyases to damaged CNS tissue changes the environment in a manner that promotes axon regeneration (Moon et al., 2001; Bradbury et al., 2002; Zuo et al., 2002). This effect is not limited to damaged CNS tissue, because GAG lyases also modify axonal pathfinding behavior in developing organisms (Chung et al., 2000; Becker and Becker, 2002). These findings show that the GAG chains are involved in the inhibition of axon regeneration. Whether this is attributable to a direct effect of the GAGs on regenerating neurons is unknown. Glycosaminoglycan chains organize the structure of the ECM (Yamaguchi, 2000), and they bind small molecules, including growth factors (Milev et al., 1998a,b; Goretzki et al., 1999). In the case of phosphacan and NG2, the CS GAG chains increase the affinity of the protein for neuritogenic factors such as bFGF. Thus, it is possible that CSPGs might sequester growth factors, and on degradation of the GAG chains, these molecules may be released and then be able to interact with their neuronal receptors. Furthermore, the association of cell surface PGs such as NG2 with membranetype matrix metalloproteinases (MMPs) is dependent on the CS GAG chains (Iida et al., 2001). Removal of the GAG chains in vivo might also release proteases that could have complex effects on the structure of the glial scar and its ability to act as a barrier for axon regeneration.

Little is known about the structure of the juxtamembrane domain 3, although it participates in multiple functions, including growth factor binding, plasminogen binding, and, as shown here, perturbation of growth cone function (Goretzki et al., 1999, 2000). The inhibitory activity of a fusion protein containing only domain 3 is quantitatively similar to the activities of either domain 1 alone or the entire ECD of NG2. This supports the idea that the separate domains of the NG2 core protein are independent and redundant functional units (Goretzki et al., 1999, 2000).

This redundancy has important implications for how NG2 might act to inhibit axon regeneration at sites of CNS injury. Although NG2 is found predominantly as an integral membrane protein, it can be secreted or shed from the cell surface via extra-
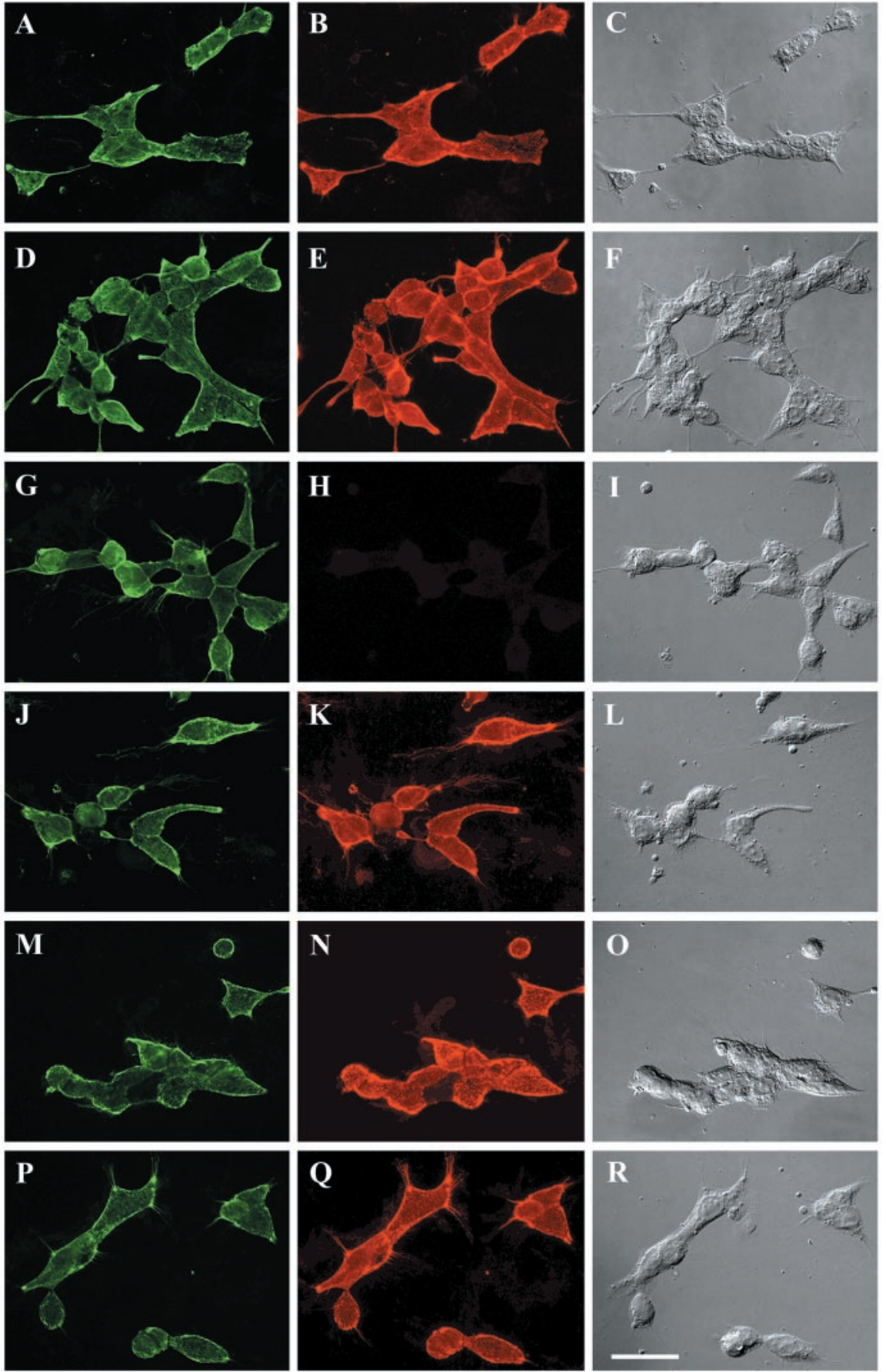

Figure 8. Anti-D3N antibody has limited binding to NG2 when it is expressed on the cell surface. 293-NG2 (A-L) and 293-D3 (M-R) cells were immunofluorescently stained with anti-NG2 antibodies as described in Materials and Methods. The following antibodies were used: $A, D, G, J, M, P$, rabbit anti-NG2; $B$, monoclonal anti-D1; E, monoclonal anti-D2; $H$, N, monoclonal anti-D3N; and $K, Q$, monoclonal anti-D3. Each monoclonal antibody was used at $1 \mu \mathrm{g} / \mathrm{ml}$, and imaging exposure times were identical for each panel. The third vertical column shows the cells using DIC optics. Although anti-D1, anti-D2, and anti-D3 stain the 293-NG2 cells robustly, the signal from anti-D3N staining is significantly weaker. Anti-D3N stains the 293-D3 cells as well as does anti-D3. Scale bar, $50 \mu \mathrm{m}$.

cellular proteolysis (Nishiyama et al., 1995). The secretion of NG2 is thought to occur at glial scars (Asher et al., 2001; Jones et al., 2002). Little is known about how this proteolytic event may be regulated. Although NG2 is a good substrate for MMP3, mRNAs encoding MMP3 have not been detected in the damaged CNS (Muir et al., 2002). Despite these uncertainties, it is clear that levels of NG2 increase after brain or spinal cord injury (Levine, 1994; Asher et al., 2001; Zhang et al., 2001; Jones et al., 2002). 
Thus it is possible that damage increases the accessibility of NG2 as it does for other growth-inhibitory molecules such as MAG, which is normally associated with the axon-myelin interface but can be released in a soluble form after injury (Trapp et al., 1989; Tang et al., 1997, 2001). The monoclonal antibody staining data shown in Figure 8 suggest that when NG2 is an integral membrane protein, regions within domain 3 that are likely to be directly involved in growth inhibition are probably inaccessible. In this situation, domain 1 is sufficient to inhibit growth. When NG2 is secreted or shed from the cell surface, parts of domain 3 would become accessible. Thus multiple regions of NG2 can inhibit axon regeneration in vivo depending on the conformational state of the molecule. Blocking inhibitory molecules with antibodies has been one of several strategies that can promote regeneration in experimentally injured animals (Fouad et al., 2001). These two regions, domains 1 and 3, will be important targets for immunological neutralization in future studies of axon regeneration in vivo.

\section{References}

Asher RA, Morgenstern DA, Moon LD, Fawcett JW (2001) Chondroitin sulphate proteoglycans: inhibitory components of the glial scar. Prog Brain Res 132:611-619.

Bandtlow CE, Zimmermann DR (2000) Proteoglycans in the developing brain: new conceptual insights for old proteins. Physiol Rev 80:1267-1290.

Battye R, Stevens A, Perry RL, Jacobs JR (2001) Repellent signaling by Slit requires the leucine-rich repeats. J Neurosci 21:4290-4298.

Becker CG, Becker T (2002) Repellent guidance of regenerating optic axons by chondroitin sulfate glycosaminoglycans in zebrafish. J Neurosci 22:842-853.

Bixby JL, Baerwald-De la Torre K, Wang C, Rathjen FG, Ruegg MA (2002) A neuronal inhibitory domain in the $\mathrm{N}$-terminal half of agrin. J Neurobiol 50:164-179.

Bovolenta P, Fernaud-Espinosa I (2000) Nervous system proteoglycans as modulators of neurite outgrowth. Prog Neurobiol 61:113-132.

Bradbury EJ, Moon LD, Popat RJ, King VR, Bennett GS, Patel PN, Fawcett JW, McMahon SB (2002) Chondroitinase ABC promotes functional recovery after spinal cord injury. Nature 416:636-640.

Burg MA, Tillet E, Timpl R, Stallcup WB (1996) Binding of the NG2 proteoglycan to type VI collagen and other extracellular matrix molecules. J Biol Chem 271:26110-26116.

Chen JH, Wen L, Dupuis S, Wu JY, Rao Y (2001) The N-terminal leucinerich regions in Slit are sufficient to repel olfactory bulb axons and subventricular zone neurons. J Neurosci 21:1548-1556.

Chen ZJ, Ughrin Y, Levine JM (2002) Inhibition of axon growth by oligodendrocyte precursor cells. Mol Cell Neurosci 20:125-139.

Chung KY, Taylor JS, Shum DK, Chan SO (2000) Axon routing at the optic chiasm after enzymatic removal of chondroitin sulfate in mouse embryos. Development 127:2673-2683.

Cornish T, Chi J, Johnson S, Lu Y, Campanelli JT (1999) Globular domains of agrin are functional units that collaborate to induce acetylcholine receptor clustering. J Cell Sci 112:1213-1223.

Cox EC, Muller B, Bonhoeffer F (1990) Axonal guidance in the chick visual system: posterior tectal membranes induce collapse of growth cones from the temporal retina. Neuron 2:31-37.

Davies SJ, Goucher DR, Doller C, Silver J (1999) Robust regeneration of adult sensory axons in degenerating white matter of the adult rat spinal cord. J Neurosci 19:5810-5822.

Dou C-L, Levine JM (1994) Inhibition of neurite growth by the NG2 chondroitin sulfate proteoglycan. J Neurosci 14:7616-7628.

Dou C-L, Levine JM (1995) Differential effects of glycosaminoglycans on neurite growth on laminin and L1 substrates. J Neurosci 15:8053-8066.

Dou C-L, Levine JM (1997) Identification of a neuronal cell surface receptor for a growth inhibitory chondroitin sulfate proteoglycan (NG2). J Neurochem 68:1021-1030.

Fawcett JW, Asher RA (1999) The glial scar and central nervous system repair. Brain Res Bull 49:377-391.

Fidler PS, Schuette K, Asher RA, Dobbertin A, Thornton SR, Calle-Patino Y, Muir E, Levine JM, Geller HM, Rogers JH, Faissner A, Fawcett JW (1999) Comparing astrocytic cell lines that are inhibitory or permissive for axon growth: the major axon-inhibitory proteoglycan is NG2. J Neurosci 19:8778-8788.

Fouad K, Dietz V, Schwab ME (2001) Improving axonal growth and functional recovery after experimental spinal cord injury by neutralizing myelin associated inhibitors. Brain Res Brain Res Rev 36:204-212.

Friedlander DR, Milev P, Karthikeyan L, Margolis RK, Margolis R, Grumet M (1994) The neuronal chondroitin sulfate proteoglycan neurocan binds to the neural cell adhesion molecules NG-CAM/L1/NILE and N-CAM, and inhibits neuronal adhesion and neurite outgrowth. J Cell Biol 125:669-680.

Goretzki L, Burg MA, Grako KA, Stallcup WB (1999) High-affinity binding of basic fibroblast growth factor and platelet-derived growth factor-AA to the core protein of the NG2 proteoglycan. J Biol Chem 274:16831-16837.

Goretzki L, Lombardo CR, Stallcup WB (2000) Binding of the NG2 proteoglycan to kringle domains modulates the functional properties of angiostatin and plasmin(ogen). J Biol Chem 275:28625-28633.

GrandPre T, Li S, Strittmatter SM (2002) Nogo-66 receptor antagonist peptide promotes axonal regeneration. Nature 417:547-551.

Hartmann U, Maurer P (2001) Proteoglycans in the nervous system-the quest for functional roles in vivo. Matrix Biol 20:23-35.

Hatten ME (1985) Neuronal regulation of astroglial morphology and proliferation in vitro. J Cell Biol 100:384-396.

Herndon ME, Lander AD (1990) A diverse set of developmentally regulated proteoglycans is expressed in the rat central nervous system. Neuron 4:949-961.

Hodor PG, Illies MR, Broadley S, Ettensohn CA (2000) Cell-substrate interactions during sea urchin gastrulation: migrating primary mesenchyme cells interact with and align extracellular matrix fibers that contain ECM3, a molecule with NG2-like and multiple calcium-binding domains. Dev Biol 222:181-194.

$\mathrm{Hu} \mathrm{H}$ (2001) Cell-surface heparan sulfate is involved in the repulsive guidance activities of Slit2 protein. Nat Neurosci 4:695-701.

Hutter H, Vogel BE, Plenefisch JD, Norris CR, Proenca RB, Spieth J, Guo C, Mastwal S, Zhu X, Scheel J, Hedgecock EM (2000) Conservation and novelty in the evolution of cell adhesion and extracellular matrix genes. Science 287:989-994.

Iida J, Pei D, Kang T, Simpson MA, Herlyn M, Furcht LT, McCarthy JB (2001) Melanoma chondroitin sulfate proteoglycan regulates matrix metalloproteinase-dependent human melanoma invasion into type I collagen. J Biol Chem 276:18786-18794.

Jones LL, Yamaguchi Y, Stallcup WB, Tuszynski MH (2002) NG2 is a major chondroitin sulfate proteoglycan produced after spinal cord injury and is expressed by macrophages and oligodendrocyte progenitors. J Neurosci 22:2792-2803.

Koppel AM, Raper JA (1998) Collapsin-1 covalently dimerizes, and dimerization is necessary for collapsing activity. J Biol Chem 273:15708-15713.

Lehmann JM, Riethmuller G, Johnson JP (1989) MUC18, a marker of tumor progression in human melanoma, shows sequence similarity to the neural cell adhesion molecules of the immunoglobulin superfamily. Proc Natl Acad Sci USA 86:9891-9895.

Levine JM (1994) Increased expression of the NG2 chondroitin-sulfate proteoglycan after brain injury. J Neurosci 14:4716-4730.

Levine JM, Card JP (1987) Light and electron microscope localization a cell surface antigen (NG2) in the rat cerebellum: association with smooth protoplasmic astrocytes. J Neurosci 7:2711-2720.

Levine JM, Nishiyama A (1996) The NG2 chondroitin sulfate proteoglycan: a multifunctional proteoglycan associated with immature cells. Perspect Dev Neurobiol 3:245-259.

Levine JM, Stallcup WB (1987) Plasticity of developing cerebellar cells in vitro studies with antibodies against the NG2 antigen. J Neurosci 7:2721-2731.

Levine JM, Enquist LW, Card JP (1998) Reactions of oligodendrocyte precursor cells to alpha herpes virus infection of the central nervous system. Glia 23:316-328.

Levine JM, Reynolds R, Fawcett JW (2001) The oligodendrocyte precursor cell in health and disease. Trends Neurosci 24:39-47.

Mark MR, Chen J, Hammonds RG, Sadick M, Godowsk PJ (1996) Characterization of Gas6, a member of the superfamily of G domain-containing proteins, as a ligand for Rse and Axl. J Biol Chem 271:9785-9789.

Martin S, Levine AK, Chen ZJ, Ughrin Y, Levine JM (2001) Deposition of the NG2 proteoglycan at nodes of Ranvier in the peripheral nervous system. J Neurosci 21:8119-8128.

Milev P, Friedlander DR, Sakurai T, Karthikeyan L, Flad M, Margolis RK, 
Grumet M, Margolis RU (1994) Interactions of the chondroitin sulfate proteoglycan phosphacan, the extracellular domain of a receptor-type protein tyrosine phosphatase, with neurons, glia, and neural cell adhesion molecules. J Cell Biol 127:1703-1715.

Milev P, Maurel P, Haring M, Margolis RK, Margolis RU (1996) TAG-1/ axonin-1 is a high affinity ligand of neurocan, phosphacan/proteintyrosine phosphatase- $\zeta / \beta$, and N-CAM. J Biol Chem 271:15716-15723.

Milev P, Chiba A, Haring M, Rauvala H, Schachner M, Ranscht B, Margolis RK, Margolis RU (1998a) High affinity binding and overlapping localization of neurocan and phosphacan/protein-tyrosine phosphatase- $\zeta / \beta$ with tenascin-R, amphoterin, and the heparin-binding growth-associated molecule. J Biol Chem 273:6998-7005.

Milev P, Monnerie H, Popp S, Margolis RK, Margolis RU (1998b) The core protein of the chondroitin sulfate proteoglycan phosphacan is a highaffinity ligand of fibroblast growth factor-2 and potentiates its mitogenic activity. J Biol Chem 273:21439-21442.

Moon LDF, Asher RA, Rhodes KE, Fawcett JW (2001) Regeneration of CNS axons back to their original target following treatment of adult rat brain with chondroitinase ABC. Nat Neurosci 4:465-466.

Moon LDF, Asher RA, Rhodes KE, Fawcett JW (2002) Relationship between sprouting axons, proteoglycans and glial cells following unilateral nigrostriatal axotomy in the adult rat. Neuroscience 109:101-117.

Muir EM, Adcock KH, Morganstern DS, Clayton R, von Stillfried N, Rhodes K, Ellis C, Fawcett JW, Rogers JH (2002) Matrix metalloproteases and their inhibitors are produced by overlapping populations of activated astrocytes. Brain Res Mol Brain Res 100:103-117.

Nishiyama A, Dahlin KJ, Prince JT, Johnstone SR, Stallcup WB (1991) The primary sequence of NG2, a novel membrane spanning proteoglycan. J Cell Biol 114:359-371.

Nishiyama A, Lin X-H, Stallcup WB (1995) Generation of truncated forms of the NG2 Proteoglycan by cell surface proteolysis. Mol Biol Cell 6:1819-1832.

Oakley RA, Tosney KW (1991) Peanut agglutinin and chondroitin 6-sulfate are molecular markers for tissues that act as barriers to axon advance in the avian embryo. Dev Biol 147:187-206.

Ong WY, Levine JM (1999) A light and electron microscopic study of NG2 chondroitin sulfate proteoglycan-positive oligodendrocyte precursor cells in the normal and kainate-lesioned rat hippocampus. Neuroscience 92:83-95.

Ronca F, Andersen JS, Paech V, Margolis RU (2001) Characterization of Slit protein interactions with glypican-1. J Biol Chem 276:29141-29147.

Schmalfeldt M, Bantlow CE, Dours-Zimmermann MT, Winterhalter KH, Zimmermann DR (2000) Brain derived versican V2 is a potent inhibitor of axonal growth. J Cell Sci 113:807-816.

Snow DM, Steindler DA, Silver J (1990) Molecular and cellular characterization of the glial roof plate of the spinal cord and optic tectum: a possible role for a proteoglycan in the development of an axon barrier. Dev Biol 138:359-376.

Stallcup WB, Dahlin-Huppe K (2001) Chondroitin sulfate and cytoplasmic domain-dependent membrane targeting of the NG2 proteoglycan promote retraction fiber formation and cell polarization. J Cell Sci 114:23152325.

Stallcup WB, Beasley L, Levine JM (1983) Cell surface molecules that characterize different stages in the development of cerebellar interneurons. Cold Spring Harb Symp Quant Biol 48:761-774.

Talts JF, Andac Z, Gohring W, Brancaccio A, Timpl R (1999) Binding of the $\mathrm{G}$ domain of laminin alpha1 and alpha2 chains and perlecan to heparin, sulfatides, alpha-dystroglycan and several extracellular matrix proteins. EMBO J 18:863-870.

Tang S, Woodhall RW, Shen YJ, deBellard ME, Saffell JL, Doherty P, Walsh FS, Filbin MT (1997) Soluble myelin-associated glycoprotein (MAG) found in vivo inhibits axonal regeneration. Mol Cell Neurosci 9:333-346.

Tang S, Qiu J, Nikulina E, Filbin MT (2001) Soluble myelin-associated glycoprotein release from damaged white matter inhibits axonal regeneration. Mol Cell Neurosci 18:250-269.

Tillet E, Ruggiero F, Nishiyama A, Stallcup WB (1997) The membranespanning proteoglycan NG2 binds to collagens V and VI through the central nonglobular domain of its core protein. J Biol Chem 272:10769-107776.

Timpl R, Tisi D, Taltrs JF, Andac Z, Sasaki T, Hohnenester E (2000) Structure and function of laminin G modules. Matrix Biol 19:309-317.

Trapp BD, Andrews SB, Cootauco C, Quarles R (1989) The myelinassociated glycoprotein is enriched in multivesicular bodies and periaxonal membranes of actively myelinating oligodendrocytes. J Cell Biol 109:2417-2426.

Tuttle R, Schlaggar BL, Braisted JE, O’Leary DDM (1995) Maturationdependent upregulation of growth-promoting molecules in developing cortical plate controls thalamic and cortical neurite growth. J Neurosci 15:3039-3052.

Yamada H, Fredette B, Shitara K, Hagihara K, Miura R, Ranscht B, Stallcup WB, Yamaguchi Y (1997) The brain chondroitin sulfate proteoglycan brevican associates with astrocytes ensheathing cerebellar glomeruli and inhibits neurite outgrowth from granule neurons. J Neurosci 17:7784-7795.

Yamaguchi Y (2000) Lecticans: organizers of the brain extracellular matrix. Cell Mol Life Sci 57:276-289.

Zhang Y, Tohyama K, Winterbottom JK, Haque NS, Schachner M, Lieberman AR, Anderson PN (2001) Correlation between putative inhibitory molecules at the dorsal root entry zone and failure of dorsal root axonal regeneration. Mol Cell Neurosci 17:444-459.

Zuo J, Neubauer D, Graham J, Krekoski CA, Ferguson TA, Muir D (2002) Regeneration of axon after nerve transection repair is enhanced by degradation of chondroitin sulfate proteoglycan. Exp Neurol 176:221-228. 